\title{
Repozytorium DSpace względem zaleceń Web 2.0
}

\section{Wprowadzenie}

B udowa instytucjonalnych repozytoriów jest, lub w niedalekiej przyszłości będzie, najbardziej zauważalnym przejawem urzeczywistniania koncepcji $2.0 \mathrm{w}$ nauce. Rozważając to zjawisko w kontekście rozwoju informacji naukowej, należy wskazać na coraz większą popularność takich terminów, jak Nauka 2.0 ${ }^{1}$ czy Biblioteka 2.0 (ang. Library 2.0) ${ }^{2}$, ale przede wszystkim Sieć 2.0 (ang. Web 2.0) ${ }^{3}$ - terminu leżącego u podstaw całej klasyfikacji, a dającego początek wszelkim dywagacjom oraz pomysłom na zmiany i rozwiązania tworzone w duchu Internetu Drugiej Generacji. DSpace ${ }^{4}$ jako platforma przeznaczona dla repozytorium instytucjo-

${ }^{1}$ S. Cisek, Nauka 2.0: nowe narzędzia komunikacji naukowej [on-line]. E-prints in Library and Information Science [dostęp 15 lipca 2009]. Dostępny w World Wide Web: http://eprints.rclis.org/12894/1/nauka_2.0.pdf.

2 J. M. Maness, Library 2.0 Theory: Web 2.0 and Its Implications for Libraries. Webology [on-line] 2006, vol. 3, no. 2 [dostęp 15 lipca 2009]. Dostępny w World Wide Web: http://www.webology.ir/2006/v3n2/a25.html; G. Gmiterek, Library 2.0. Możliwości zastosowania Web $2.0 \mathrm{w}$ bibliotekach polskich. Biuletyn EBIB [on-line] 2007, nr 4 (85) [dostęp 15 lipca 2009]. Dostępny w World Wide Web: http://www.ebib.info/2007/85/ a.php?gmiterek.

3 T. O'Reilly, What Is Web 2.0: Design Patterns and Business Models for the Next Generation of Software [on-line]. O’Reilly Media [dostęp 15 lipca 2009]. Dostępny w World Wide Web: http://www.oreillynet.com/pub/a/oreilly/tim/news/2005/09/30/what-isweb-20.html.

${ }^{4}$ S. MacKenzie, DSpace for E-Print Archives. High Energy Physics Libraries Webzine [on-line] 2004, iss. 9 [dostęp 15 lipca 2009]. Dostępny w World Wide Web: http://library. 
nalnego wpisuje się we wszystkie wyżej wymienione kategorie. Z jednej strony, jest oprogramowaniem sieciowym, którego rola i wykonanie są zbieżne z wytycznymi Web 2.0, z drugiej - jego użytkowanie należy postrzegać jako przejaw aktywności instytucji naukowych skierowanej ku Nauce 2.0. W aspekcie przekształcania się bibliotek w wersję 2.0, DSpace trzeba wreszcie traktować także jako narzędzie powstałe w nurcie Library 2.0 - narzędzie bardzo popularne, co należy podkreślić. Jednym z mierników tej popularności jest choćby liczba repozytoriów działających na podstawie tego oprogramowania. Dane pochodzące z serwisu OpenDOAR, gromadzącego informacje o uznanych, światowych repozytoriach naukowych, wskazują, że z 1425 repozytoriów zarejestrowanych na dzień 15 lipca 2009 r. 426 (zdecydowanie najwięcej) korzysta właśnie z DSpace (por. rysunek 1).

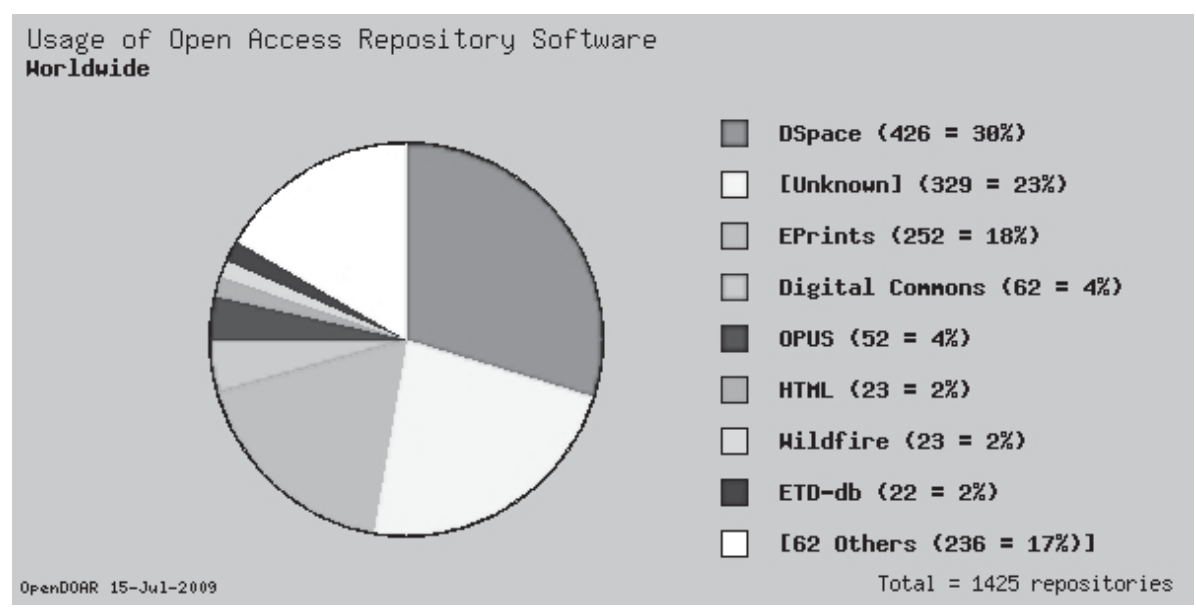

Rysunek 1. Popularność oprogramowania obsługującego repozytoria wg OpenDoar

Źródło: Usage of Open Access Repository Software - Worldwide [on-line]. The Directory of Open Access Repositories - OpenDOAR [dostęp 15 lipca 2009]. Dostępny w World Wide Web: http://www.opendoar.org/onechart.php?cID=\&ctID=\&rtI$\mathrm{D}=\& \mathrm{clID}=\& \mathrm{IID}=$ \&potID=\&rSoftWareName=\&search=\&groupby=r.rSoftWareName\&orderby=Tally $\% 20$ DESC \&charttype=pie $\&$ width $=600$ \&height $=300 \&$ caption=Usage\%20of\%200pen\%20Access\%20Repository\%20Software\%20\%20Worldwide.

cern.ch/HEPLW/9/papers/3/; P. Śliwiński, DSpace, internetowe repozytorium Massachusetts Institute of Technology [on-line]. FIDKAR M@łopolski [dostęp 15 lipca 2009]. Dostępny w World Wide Web: http://fidkar.wbp.krakow.pl/fidkar/uj/sliwinski_przemyslaw_dspace_mit.pdf. 
Mimo że DSpace w pełni zasługuje na miano narzędzia spełniającego kryteria nurtu Web 2.0, interesujące wydaje się zbadanie, na ile nim jest, w jakim stopniu można je rozbudować i - co najważniejsze - w jaki sposób odpowiada na potrzeby tzw. Użytkownika 2.0. Tego typu kwestie próbuje rozstrzygnąć niniejszy artykuł. Zawarta w nim prezentacja platformy DSpace ma charakter dwutorowy. Z jednej strony, autor umiejscawia ją na płaszczyźnie Internetu, pokazując jej ogólne założenia programowe, z drugiej - przedstawia jej możliwości w stosunku do oczekiwań, jakie stwarza praktyczny - bo poparty wieloma już przykładami wdrożeń, ale też rozbudowany - gdyż łączy znaczną liczbę rozwiązań - model Sieci 2.0. Przybliżając założenia tego modelu, autor odwołuje się głównie do kultowego już - jak można wnioskować chociażby z liczby cytowań - artykułu Tima O’Reilly'ego ${ }^{5}$. Poniższe omówienie cechuje jednak podejście bardziej użytkowe (naturalnie kosztem ważnych, lecz cały czas ocierających się - zdaniem autora - o uogólnienia rozważań o przyszłości nauki w jej nowej wersji). Na takie bliższe i bardziej praktyczne przyjrzenie się DSpace pozwala nie tylko dokumentacja zamieszczona w Internecie, ale przede wszystkim otwarty status oprogramowania, a co za tym idzie - możliwość nieskrępowanego testowania przez potencjalnego użytkownika ${ }^{6}$.

\section{Załozienia platformy DSpace a wytyczne Web 2.0}

Co hoć w procesie budowy repozytoriów cyfrowych dla Sieci 2.0 można opierać się na wzorcach wypracowanych przez twórców istniejącego już oprogramowania lub ukształtowanych przez badaczy samej koncepcji 2.0, tak naprawdę siła tego nurtu tkwi w jego niedookreśloności. Irracjonalna wydaje się przecież implementacja jakiejkolwiek platformy, w której z góry przewiduje się konieczność jej całkowitej przebudowy.

\footnotetext{
5 T. O’Reilly, dz. cyt.

${ }^{6}$ System udostępniono w formie Live CD, czyli na bootowalnym nośniku (CD-ROM, DVD, pamięć flash), w sposób umożliwiający uruchomienie w pamięci RAM bez potrzeby instalowania go na dysku twardym komputera. Jest to coraz popularniejsza metoda upowszechniania programów w celach demonstracyjnych. Często Live CD powstaje na bazie dystrybucji Linuksa, w tym przypadku na bazie dystrybucji Ubuntu - darmowego i elastycznego systemu operacyjnego przystosowanego do wykorzystywania bezpośrednio po instalacji. Por. C. Yates, S. Lewis, DSpace Live CD (version 1.5.1 beta) [on-line]. CADAIR. Aberystwyth University's online research repository [dostęp 15 lipca 2009]. Dostępny w World Wide Web: http://hdl.handle.net/2160/641.
} 
Projekt DSpace został opracowany wspólnie przez bibliotekę największej uczelni technicznej na świecie Massachusetts Institute of Technology i firmę Hewlett-Packard. System można bezpłatnie pobierać i używać jako własne repozytorium do przechowywania i udostępniania skanów, fotografii, filmów, książek i wielu innych rodzajów treści. Założenia, na których opiera się oprogramowanie, są zgodne z wszelkimi postulatami Web 2.0. Wśród najważniejszych z nich należy wymienić: dostępność, uniwersalność, elastyczność, innowacyjność oraz rozwój zgodny z oczekiwaniami użytkownika i przy jego współpracy. Ponieważ dotąd nie wypracowano szczegółowych modeli rozpoznawania potrzeb i możliwości Internetu Drugiej Generacji, sposób rozumienia i realizacji wszystkich wyżej wymienionych wytycznych zależy tylko od administratora repozytorium i jest wynikiem jego relacji z użytkownikami. Choć podczas wdrażania DSpace - głównie ze względów praktycznych - wykorzystuje się przede wszystkim dostępne już funkcjonalności, to świadomość braku barier na drodze do gruntownej przebudowy oprogramowania, jak i możliwość partycypacji w jego rozwoju stanowią o znacznej wartości tej platformy. Na pewno pomaga w tym liberalna i otwarta licencja Berkeley Software Distribution (dalej: BSD), w ramach której jest udostępniany system, a która umożliwia niemalże dowolne modyfikacje, włącznie z zastosowaniami stricte komercyjnymi. Jest ona szczególnie przydatna przy projektach długofalowych, rozwijanych i wykorzystywanych przez instytucje. Z uwagi na to, że w tego typu przedsięwzięciach często trudno zaplanować, w jaki sposób prace nad oprogramowaniem i potrzeby instytucjonalne będą kształtować się w przyszłości, możliwość minimalizacji formalnych barier wydaje się tu szczególnie cenna. W przypadku DSpace problemu nie stwarza na przykład ewentualna konieczność komercjalizacji części kodu. Sama licencja BSD stanowi zaś pewną formę promocji oprogramowania, ułatwia bowiem jego upowszechnianie oraz zachęca do partycypacji w rozwoju7. Już w kwestii licencyjnej DSpace jawi się zatem jako system w pełni gotowy do funkcjonowania w Sieci 2.0.

Sam proces tworzenia DSpace jest oparty na społeczności sieciowej wykorzystującej nowe formy komunikacji. Wsparcie organizacyjne oferuje serwis SourceForge.net ${ }^{8}$, stanowiący (według jego autorów) najwięk-

7 B. Montague, Why you should use a BSD style license for your Open Source Project [on-line]. The FreeBSD Project [dostęp 15 lipca 2009]. Dostępny w World Wide Web: http://www.freebsd.org/doc/en/articles/bsdl-gpl/article.html.

${ }^{8}$ What is SourceForge.net? [on-line]. SourceForge.net [dostęp 15 lipca 2009]. 
szą na świecie platformę łączącą projekty open source i wspierającą ich rozwój (ponad 230 tys. projektów). Zapewnia on programom o otwartym kodzie źródłowym nie tylko szeroko pojęte miejsce w Internecie, ale stwarza możliwość komunikacji pomiędzy ich współautorami (np. zgłaszanie błędów czy utrzymywanie plików na serwerze). Pomysły na rozbudowywanie DSpace pojawiają się również podczas cyklicznej imprezy Google Summer of Code ${ }^{9}$, w ramach której młodzi programiści rozwijają kod oraz dyskutują nad nowymi pomysłami. Oprócz kodu źródłowego społeczność zgromadzona wokół DSpace udostępnia także szeroką dokumentację poprzez mechanizm Wiki (znany głównie z Wikipedii - flagowego dzieła Web 2.0). Wspólną pracę nad rozwojem DSpace umożliwia wreszcie inicjatywa DSpace Federation, która promuje i konsoliduje instytucje biorące udział w budowaniu platformy. Aktualnie - oprócz rozwoju kolejnych wydań specyfikacji 1.0 (obecnie 1.5.1) - trwają prace nad wersją 2.0.

Skoro rozbudowa DSpace jest prowadzona z udziałem społeczności sieciowej oraz z wykorzystaniem nowych form komunikacji, a więc zgodnie z rozwiązaniami Web 2.0 i za ich pomocą, można założyć, że wynik tych prac - czyli sama platforma - również oferuje rozwiązania zintegrowane z tym nurtem. Jednym z kluczowych pomysłów DSpace wydaje się stworzenie użytkownikom zwiększonych możliwości korzystania z zasobów oraz ich aktywnego włączania się w działanie i rozwój repozytorium. Ponieważ „Sieć 2.0 nie jest siecią publikacji tekstowych" ${ }^{10}$, niezmiernie ważna jest tu odpowiednia prezentacja treści. Liczą się więc nie tyle same źródła, ile ich dostępność i możliwość indywidualnej pracy na bazie publicznie dostępnych rekordów (stąd duże znaczenie ma sposób licencjonowania treści). Dzięki otwartości oprogramowania repozytorium DSpace staje się wręcz zależne od postawy jego użytkowników i stanowi narzędzie przeznaczone bardziej dla nich samych niż dla danej instytucji. Analogicznie jak w przypadku innych systemów 2.0, i tu - dzięki rozbudowanym opcjom pomocy i modułom komunikacji - użytkownicy posiadają znaczący wpływ na kształt prezentowanych treści, jak i sposób rozwoju platformy (możliwość testowania, dodawania nowych i ulepszania istniejących funkcjonalności).

Dostępny w World Wide Web: http://apps.sourceforge.net/trac/sourceforge/wiki/ What $\% 20$ is\%20SourceForge.net.

${ }^{9}$ Google Summer of Code [on-line]. Google Code [dostęp 15 lipca 2009]. Dostępny w World Wide Web: http://code.google.com/soc/.

${ }^{10} \mathrm{~J}$. M. Maness, dz. cyt. 


\section{Funkcjonalności DSpace a potrzeby użytkowników końcowych}

Choć w sferze komunikacji i pomocy dla potencjalnego użytkownika DSpace wprowadza własne rozwiązania, trzeba przyznać, że są to raczej typowe mechanizmy Sieci Pierwszej Generacji. Należy do nich zaliczyć formularze kontaktowe, opcje umożliwiające przesyłanie wiadomości i powiadomień pocztą elektroniczną, standardową pomoc tekstową (por. rysunek 2) czy FAQ - najczęściej zadawane pytania.

\section{DSPACE HELP}

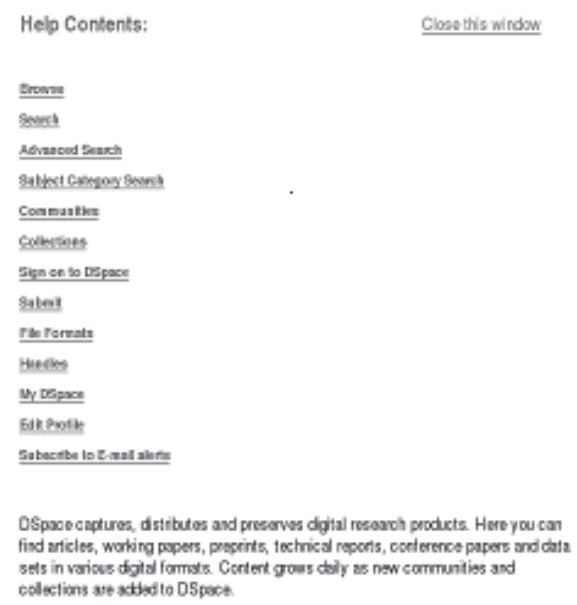

Rysunek 2. Prezentacja wbudowanej pomocy dla użytkowników DSpace

Źródło: C. Yates, S. Lewis, DSpace Live CD (version 1.5.1 beta) [on-line]. CADAIR. Aberystwyth University's online research repository [dostęp 15 lipca 2009]. Dostępny w World Wide Web: http://hdl.handle.net/2160/641.

Znacznie więcej możliwości DSpace oferuje administratorom systemu, udostępniając wszechstronne mechanizmy rozbudowy platformy. Podobnie jak w przypadku innych projektów, zakładając jakąkolwiek modyfikację, i w tym przypadku należy pamiętać jednak, że wszelkie dodatki czy udogodnienia powinny być zintegrowane w jednolitym interfejsie. Dla poprawnego funkcjonowania repozytorium niezwykle istotne wydaje się zapewnienie różnorodnych form komunikacji synchronicznej ${ }^{11}$, przebie-

\footnotetext{
11 Tamże.
} 
gającej na linii instytucja-użytkownik w czasie rzeczywistym (choćby poprzez wbudowanie komunikatorów internetowych). Ułatwiona komunikacja to także możliwość interakcji między użytkownikami. Sposobem na realizację takiego kontaktu mogą być blogi, systemy komentarzy czy serwisy typu wiki. Rozbudowując repozytorium, warto pamiętać o tego typu funkcjonalnościach DSpace, z powodzeniem realizowanych już w oficjalnym serwisie wiki systemu ${ }^{12}$.

Mimo tego, że reagowanie na potrzeby każdego - również zewnętrznego - użytkownika repozytorium to bez wątpienia jeden $\mathrm{z}$ atutów oprogramowania DSpace, to wydaje się, że w procesie budowy repozytoriów i postępującego rozwoju oprogramowania sieciowego większą uwagę należy poświęcić tworzeniu multimedialnych poradników dla użytkowników. W chwili obecnej tutoriale DSpace ograniczają się w zasadzie do podejmowania problemów zarządzania i rozbudowy programu ${ }^{13}$, nie zaś samych kwestii obsługi czy możliwości wykorzystywania repozytorium z punktu widzenia potencjalnego odbiorcy. W tym kontekście warto pamiętać, że choć ogólną identyfikację potrzeb użytkowników unaoczniają statystyki i zapisy w rejestrze systemowym, to w dobie tworzenia Biblioteki 2.0 informacje te mogą okazać się niewystarczające, ponieważ tak naprawdę nie dostarczają danych na temat poczynań odwiedzających, wdrożonych strategii wyszukiwania czy zaistniałych problemów z obsługą. Być może w tym kontekście w repozytoriach DSpace należy rozważyć także dodatkowe, zewnętrzne badania użytkowników.

Na poczucie satysfakcji użytkowników niewątpliwie wpływa sam wygląd serwisu w przeglądarce internetowej czy też jego użyteczność (ang. web-usability). DSpace i formalnie, i technicznie umożliwia zmianę powłoki systemowej zgodnie z koncepcją i wymogami danej instytucji. Dla potrzeb programistów został opracowany szereg instrukcji dotyczących wprowadzania modyfikacji graficznych i dopasowania układu treści re-

12 DSpace Wiki [on-line] [dostęp 15 lipca 2009]. Dostępny w World Wide Web: http://wiki.dspace.org/index.php/Main_Page.

${ }_{13}$ T. Donohue, S. Phillips, D. Salo, DSpace How-To Guide: Tips and tricks for managing common DSpace chores [on-line]. IDEALS. Illinois Digital Environment For Access to Learning and Scholarship [dostęp 15 lipca 2009]. Dostępny w World Wide Web: https://www. ideals.uiuc.edu/bitstream/2142/1043/3/DspaceHowToGuide.pdf; DSpace 1.5.1 Manual [on-line]. DSpace.org [dostęp 15 lipca 2009]. Dostępny w World Wide Web: http://www. dspace.org/1_5_1Documentation/DSpace-Manual.pdf. 
pozytorium oraz jego optymalizacji i pozycjonowania w przeglądarkach internetowych czy urządzeniach przenośnych ${ }^{14}$.

Choć budowa każdego repozytorium to ogromny krok w stronę poprawy warunków pracy współczesnego naukowca czy studenta, samo jego uruchomienie może okazać się niewystarczające, by zasób taki traktować jako typowy przejaw Sieci 2.0. 0 realizacji tej idei - o czym już wielokrotnie wspomniano - można mówić bowiem dopiero wówczas, gdy treść danego serwisu jest generowana przez samych użytkowników. Możliwość taką stwarzają interaktywne opcje komunikacji. Poza - opisanymi już - różnorodnymi formami komunikacji synchronicznej, szczególnego znaczenia w tym kontekście nabiera zapewnienie komunikacji na płaszczyźnie poziomej - pomiędzy samymi użytkownikami - oraz dbanie o dynamiczną treść $\mathrm{w}$ atrakcyjnej formie, często i sukcesywnie aktualizowaną, w połączeniu z obserwacją jej wykorzystania ${ }^{15}$. Dobrym przykładem tego typu rozwiązań są narzędzia służące dzieleniu się wartościowymi źródłami. W DSpace koordynacja dodawania i merytorycznej weryfikacji treści jest uwzględniona i leży po stronie administratorów systemu. Same profile użytkowników nie są zbytnio rozbudowane, a relacje między nimi polegają głównie na ewentualnym przypisywaniu do konkretnych grup tematycznych i organizacyjnych (tzw. communities) czy wspólnej opiece nad daną kolekcją rekordów. Trudno tu mówić o typowych publicznych profilach, znanych z popularnych serwisów internetowych, czy mechanizmach przeradzających DSpace w sieć społecznych oddziaływań. Choć pełna dowolność konstruowania zawartości rekordów repozytorium nie jest tu ani dopuszczalna, ani wskazana, to umożliwienie użytkownikom jej komentowania czy oznaczania własnymi słowami kluczowymi (tzw. tagami) wydaje się słusznym rozwiązaniem. Dzięki szerokiemu zróżnicowaniu praw dostępu w obrębie danych grup tematycznych czy organizacyjnych DSpace, w systemie możliwe jest także wprowadzanie ograniczeń użytkowania niektórych zasobów i stosowanie odpowiednich procedur autoryzacji. Wszystkie źródła otacza się kontrolą administracyjną i określa dla nich prawa rozpowszechniania. Działania te podejmuje się w celu ochrony najcenniejszego elementu repozytorium, jakim jest unikalny rekord źródłowy.

\footnotetext{
14 Tamże.

15 T. O’Reilly, dz. cyt.
} 


\section{Prezentacja źródeł w DSpace}

W spółczesny Internet to przede wszystkim unikalna treść. Każdy serwis dąży do jej pozyskania różnymi metodami i z wykorzystaniem różnych mechanizmów, także dzięki zaangażowaniu jego użytkowników (jak w przypadku serwisów Web 2.0). Repozytorium instytucjonalne jako wielka wartość dodana, „opakowana” dodatkowo w nowoczesną formę, może zdobyć w świecie nieuporządkowanego Internetu znaczącą pozycję. Mając unikalną zawartość w postaci sklasyfikowanych i publicznie dostępnych źródeł, można nawet rozważać, czy jakiekolwiek repozytorium warto w ogóle wzbogacać o rozwiązania znane m.in. z serwisów społecznościowych, czy bazować jedynie na samej jakości rekordów. Podejmując decyzję o wdrożeniu nowych elementów, warto zastanowić się także nad profilem odbiorców, ich kompetencjami informacyjnymi czy poziomem ich wiedzy na temat celów funkcjonowania danego repozytorium.

Choć sposób prezentacji pojedynczego rekordu DSpace jest dość typowy (analogiczny jak w przypadku wielu baz danych czy bibliotek cyfrowych), można w nim wyróżnić także pewne dodatkowe elementy. Do opisu bibliograficznego został zastosowany format Dublin Core, który w prosty sposób można rozbudować o dodatkowe pola czy opisy pól. Można także zrezygnować z tego schematu i zastosować inne systemy katalogowania. Przykładowy rekord z repozytorium DSpace prezentuje rysunek 3.

Nietrudno zauważyć, że poza atrybutami schematu Dublic Core (obszar 1) i przypisanymi do nich danymi bibliograficznymi, ważną rolę w strukturze rekordu odgrywają metainformacje o charakterze strukturalnym, pozwalające łączyć różne dane (np. zbiór plików graficznych) w jedno, uporządkowane źródło, oraz dane administracyjne określające politykę dostępu ${ }^{16}$ (ze szczególnym uwzględnieniem licencji Creative Commons). Ponieważ wszystkie źródła w repozytorium są przyporządkowane do odpowiednich kolekcji (każda z możliwym odmiennym sposobem zarządzania), w strukturze każdego rekordu zamieszcza się informację o nazwie takiej kolekcji (obszar 2). Ponad kolekcjami mogą zostać ulokowane także grupy użytkowników (wspomniane communities), uporządkowane hierarchicznie zgodnie ze strukturą prowadzącej dane repozytorium instytucji. Następnym elementem uwidocznionym w strukturze rekordu jest opcja umożliwiająca przeglądanie lub pobieranie danego pli-

${ }^{16}$ DSpace 1.5.1 Manual... 


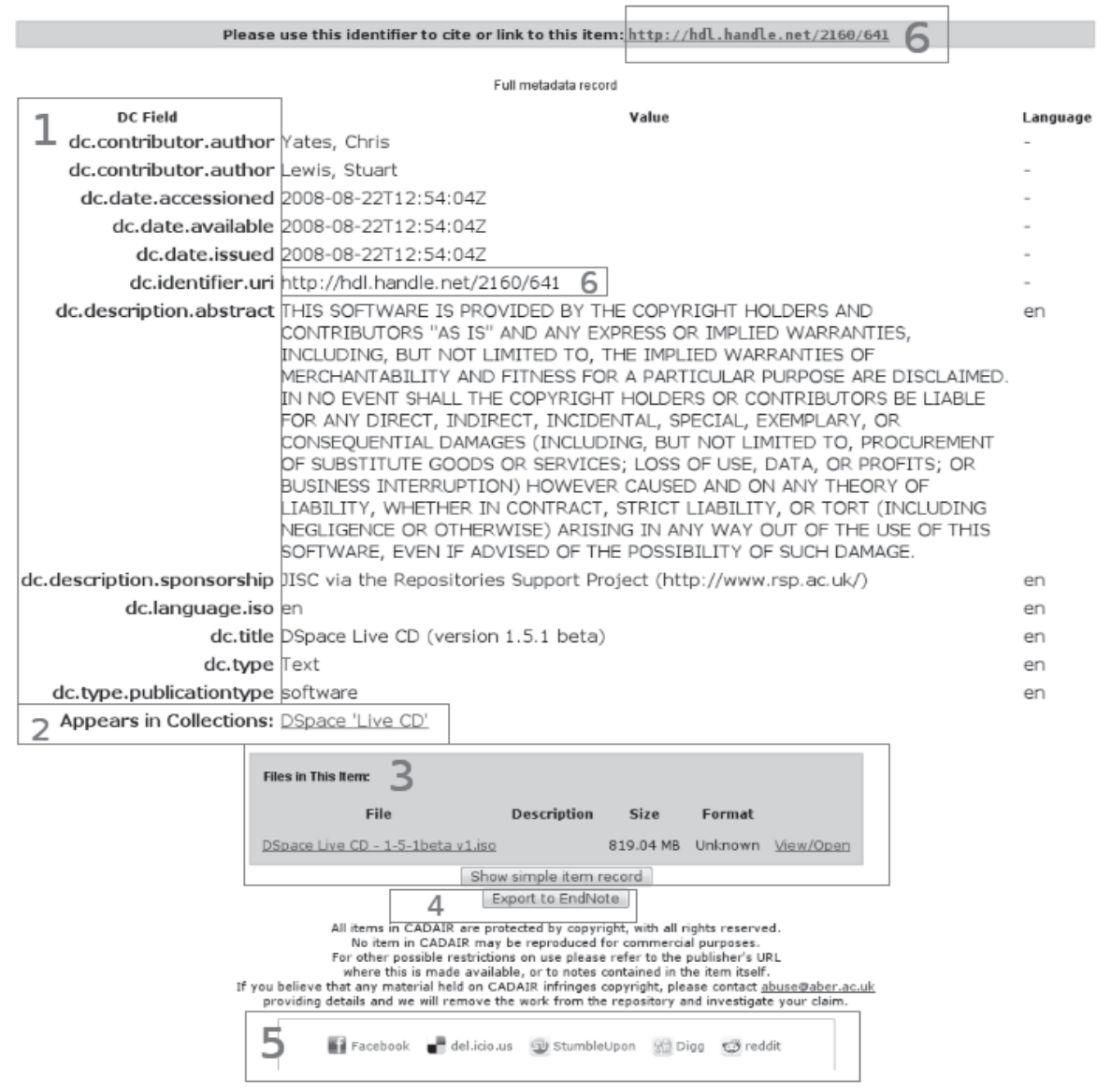

Rysunek 3. Przykładowy rekord z repozytorium DSpace

Legenda:

1. Elementy opisu bibliograficznego w formacie Dublin Core,

2. Kolekcja, do której przypisano rekord,

3. Pliki do pobrania,

4. Opcja eksportu opisu bibliograficznego do programu EndNote,

5. Logotypy serwisów społecznościowych umożliwiające przesyłanie odnośników do rekordów na profile użytkowników umieszczone w wymienionych serwisach,

6. Hiperłącze permanentne źródła.

Źródło: C. Yates, S. Lewis, DSpace Live CD (version 1.5 .1 beta) [on-line]. CADAIR. Aberystwyth University's online research repository [dostęp 15 lipca 2009]. Dostępny w World Wide Web: http://hdl.handle.net/2160/641. 
ku źródłowego (obszar 3). Innym udogodnieniem dla użytkownika jest możliwość eksportu rekordów DSpace do komercyjnych programów bibliograficznych (w przypadku prezentowanego rekordu - EndNote, na rysunku obszar 4), ułatwiających zarządzanie bibliografią i przypisami podczas redagowania tekstów naukowych oraz wyszukiwanie baz danych w Internecie. Integralnymi elementami pojedynczego rekordu są wreszcie logotypy serwisów społecznościowych (obszar 5) i łącza permanentne (ang. permanent links, permalinks) (obszar 6). Pierwsze z nich pozwalają na tworzenie listy odnośników do ulubionych rekordów w ramach profili użytkowników funkcjonujących na popularnych portalach społecznościowych, drugie - na ułatwienie procedur cytowania źródeł (odsyłacze te są krótsze, czasem mają zawartość semantyczną, która ułatwia ich zapamiętywanie) i bieżącą aktualizację dostępu do nich (nawet przy fizycznej zmianie lokalizacji źródła możliwy jest dostęp do niego).

Dodatkowym udogodnieniem z punktu widzenia rozpowszechniania informacji pochodzących z DSpace, nieuwidocznionym jednak na rysunku 3, są kanały RSS (dostępne w wersji 1.0 i 2.0). Możliwość subskrypcji i agregacji informacji tą drogą nie stanowi szczególnego novum, ale jest funkcjonalnością silnie powiązaną z Web 2.0, dynamizującą przekaz informacji ze stron internetowych, informującą o nowościach i zawartości serwisu $^{17}$. Na dzielenie się unikalną zawartością pozwala także wbudowany w DSpace protokół Open Archives Initiative’s Protocol for Metadata Harvesting (OAI-PMH), który umożliwia selektywne pobieranie metadanych opisujących obiekty cyfrowe i automatyczną wymianę informacji pomiędzy systemami gromadzącymi takie metadane a systemami chcącymi te dane uzyskać. Jest to warunek podstawowy w sytuacji, gdy repozytorium ma zostać publicznie otwarte lub gdy niektóre źródła są udostępniane tylko $\mathrm{w}$ postaci metadanych oraz abstraktów $\mathrm{z}$ wykluczeniem pełnej treści.

Na koniec warto zauważyć, że poza przeglądaniem zawartości poszczególnych rekordów, w DSpace istnieje także możliwość wyszukiwania źródeł za pomocą wbudowanego formularza zapytań. Mechanizm ten nie odbiega od rozwiązań przyjętych w wielu powszechnie wykorzystywanych bazach danych i pozwala na wyszukiwanie zarówno według kryteriów formalnych, jak i rzeczowych (por. rysunek 4).

${ }^{17}$ J. M. Maness, dz. cyt. 


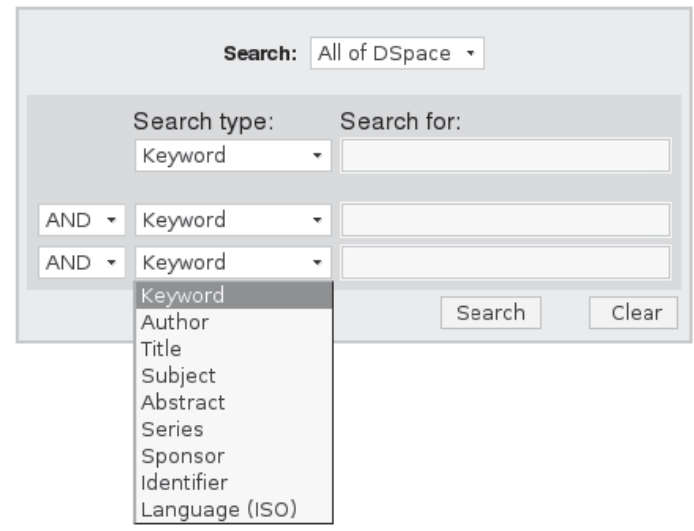

Rysunek 4. Formularz wyszukiwawczy repozytorium DSpace

Źródło: C. Yates, S. Lewis, DSpace Live CD (version 1.5 .1 beta) [on-line]. CADAIR. Aberystwyth University's online research repository [dostęp 15 lipca 2009]. Dostępny w World Wide Web: http://hdl.handle.net/2160/641.

\section{Podsumowanie}

Wrótkim zarysie, nie wnikając w aspekty programistyczne, które najlepiej pozostawić deweloperom i specjalistom, przedstawiono funkcjonalności repozytorium wykorzystującego platformę DSpace. Same założenia predestynują ten system do miana narzędzia Web 2.0. Otwarte rozwiązania i licencje, dowolność zmian oraz wykorzystania rysują ciekawą perspektywę rozwoju. Badacze koncepcji Sieci 2.0 poruszają bardzo wiele kwestii i proponują całe spektrum narzędzi, które powinny znaleźć zastosowanie w oprogramowaniu tego nurtu. Uwzględnienie wszystkich wytycznych nie wydaje się ani możliwe, ani rozsądne, gdyż grozi przerostem formy nad treścią. Również system DSpace nie spełnia wszystkich postulatów. Jeśli odpowiada jednak potrzebom danej instytucji, a rozbudowa platformy jest brana pod uwagę od chwili jej wdrożenia, to można zaryzykować stwierdzenie, że jako system powinien się sprawdzić w większości wdrożeń, w tym w ośrodkach naukowych, bibliotekach, muzeach i archiwach. Warto pamiętać, że tak jak przy serwisach nurtu Web 2.0, i w tym przypadku kluczową rolę odgrywają użytkownicy, a zwłaszcza ich współpraca z instytucją tworzącą repozytorium, nastawienie do publicznego rozpowszechnienia własnej pracy drogą elektroniczną i wreszcie zrozumienie dla idei repozytorium. Potencjał tkwi bowiem 
w unikalnym dorobku pracowników połączonym z racjonalnym sposobem jego udostępniania będącym w zgodzie z ich potrzebami ${ }^{18}$.

\section{DSpace repository towards Web 2.0 recommendations \\ Abstract}

DSpace, in this article, is described as solution for academic repository and it is compare with widely known Web 2.0 recommendations presented in an great number of web publications and today's solutions. This comparison is based on formal foundations of DSpace, possibilities which comes with this software - described in documentation (for example in handbook or wiki) - and practical implications from existing implementations. Important role in this comparison plays present user and his needs from social networks and web services he are likely incorporate to professional work. Repository should be usable for him as much as it is possible. DSpace gives administrators and institutions place to make their own upgrades and propose new solutions to increase this usability. This article is also mention about general properties and characteristic of DSpace, especially about record-making and how can end-user make the most of repository sources in Web 2.0 world.

18 T. O’Reilly, dz. cyt. 